\title{
Development and Shelf-life Extension of Cranberry Infused Caramel Paneer Bites for School Going Children
}

\author{
Simranjeet Kaur ${ }^{1,2 "}$, Sunil Kumar ${ }^{1}$ and Pavan Kumar ${ }^{2}$ \\ $1^{*}$ Division of Livestock Products Technology, FV.Sc. \& A.H., R.S. Pura, Jammu, INDIA \\ ${ }^{2}$ Department of Livestock Products Technology, GADVASU, Ludhiana, INDIA \\ *Corresponding author: S Kaur; E-mail: simarvet@gmail.com
}

Received: 29 Jan., 2021

Revised: 28 April, 2021

Accepted: 02 May, 2021

\begin{abstract}
The plenary investigation was based on the development and shelf life extension of cranberry infused caramel paneer bites for school going children. Caramel paneer bites were standardized on the basis of preliminary trials and after cooking for 10 minutes in sugar solution of $50^{\circ} \mathrm{Bx}$ strength, sensory evaluation was performed by $\mathrm{P}$ and $\mathrm{K}$ hedonic testing with 100 children (7-16 yrs) selected randomly from Jammu city. Thereafter, shelf life studies were conducted on four different formulations i.e. control (without cranberry extract), T1, T2 and T3 (with cranberry extract) at storage interval of 15 days up to spoilage at refrigeration temperature $\left(4 \pm 1^{\circ} \mathrm{C}\right)$. No significant change was observed in fat, protein and ash content of all the four formulations; however, moisture content of control formulation increased significantly throughout the storage period. In case of all the treatments, significantly lower TBARS and FFA values were analysed relative to control samples on all the days of storage. Total plate count and yeast and mould count increased above permissible limits on day 45 in control samples and on day 60 in cranberry infused treatments. Based on the results obtained, it was concluded that caramel paneer bites were well accepted by school going children with maximum shelf life of 30 days at refrigeration temperature of $4 \pm 1^{\circ} \mathrm{C}$ without appreciable loss of freshness and sensory attributes, however, its sensory and microbial acceptability could significantly be improved up to 45 days by addition of cranberry extract.
\end{abstract}

\section{HIGHLIGHTS}

(0) Cranberry extract is a rich source of numerous bioactive phyto-chemicals.

(- The cranberry extract incorporated caramel coating to paneer bites increased shelf life upto 45 days at refrigeration temperature.

Keywords: Paneer bites, cranberry extract, caramel, storage stability

Caramel is medium to dark brown confectionary product manufactured by heating of sugar with other ingredients till it becomes soft, chewy ball or a hard crack by process of sugar polymerization. Process of caramelization involves removal of water from sugar, followed by isomerisation and polymerization of the sugars into high molecular-weight compounds that contribute to the darkbrown colour of caramel. Fragmentation reaction result in low molecular weight compounds that are volatile and contributes to flavour. Mixture is heated to a point till it reached a desired cook, and depending upon the texture; caramel may be classified as soft ball $\left(112-116^{\circ} \mathrm{C}\right)$, firm ball $\left(118-120^{\circ} \mathrm{C}\right)$, a hard ball $\left(122-130^{\circ} \mathrm{C}\right)$, a crack $(160-$ $170^{\circ} \mathrm{C}$ ), or even above a crack. The resulting product could be applied as flavouring in puddings and desserts, as a filling in bonbons, as a topping for ice cream or as coatings (Kaur et al., 2018).

Cranberries are a rich source of numerous phyto-chemicals associated with anti-bacterial, anti-viral, anti-mutagenic, anti-carcinogenic, anti-angiogenic, anti-inflammatory

How to cite this article: Kaur, S., Kumar, S. and Kumar, P. (2021) Development and shelf-life extension of cranberry infused carame paneer bites for school going children. J. Anim. Res., 11(3): 527-537. Source of Support: None; Conflict of Interest: None क्ष 
and anti-oxidant properties and are used in many foods products and dietary supplements because of their ability to lower LDL cholesterol and increase HDL cholesterol and protect against urinary tract infections (Blumberg et al., 2013). Recent scientific investigations reported berry fruits such as blackberries, blueberries, cranberries, raspberries and strawberries as richest repository of numerous phytochemicals having positive impact on human health. Usually, cranberries are shelved in market as juices, sauces, dried cranberries in cereal bars, chocolates, confectionary items and health supplements in powder and extract form (Parades et al., 2010).

Paneer is a popular South-Asian variety of nonfermentative, non-renneted, non-melting and un-ripened type cottage cheese, prepared by acid coagulation of hot milk. According to the FSSAI (2006), "Paneer is a product obtained from cow or buffalo milk by precipitation with sour milk, lactic acid or citric acid. It should contain maximum $70 \%$ moisture and minimum $50 \%$ fat on dry matter basis". Paneer is a valuable source of animal protein, fat, vitamins and minerals available at a comparatively lower cost and the biological value of protein in paneer is in the range of 80 to 86 (Shrivastava and Goyal, 2007). Paneer is consumed either in raw form or in preparation of varieties of culinary dishes like palak paneer, shahi paneer, matter paneer and snacks as paneer pakora or fried paneer chunks. To date, no comprehensive study was conducted regarding development of protein rich cranberry infused caramel paneer bites for school going children. Further, shelf life of the cranberry infused caramel paneer bites was analysed at refrigeration temperature $\left(4 \pm 1^{\circ} \mathrm{C}\right)$ up to spoilage.

\section{MATERIALS AND METHODS}

\section{Source of materials}

Cow milk was procured from the Dairy farm of SKUASTJammu University and standardized to $4.5 \%$ Fat and $8.5 \%$ SNF as per the Pearson calculation. Crystalline sugar and whole milk powder were procured from the retail market of R.S. Pura. Fruit powders (mango, grape and pineapple) manufactured by Sri Nuthatch Nutricare Technologies Pvt. Ltd, Bengaluru and cranberry extract (www.vistanutrition. com), were procured from e-marketplace. Procedure for caramel preparation was standardized in the food lab of LPT department, SKUAST-Jammu.

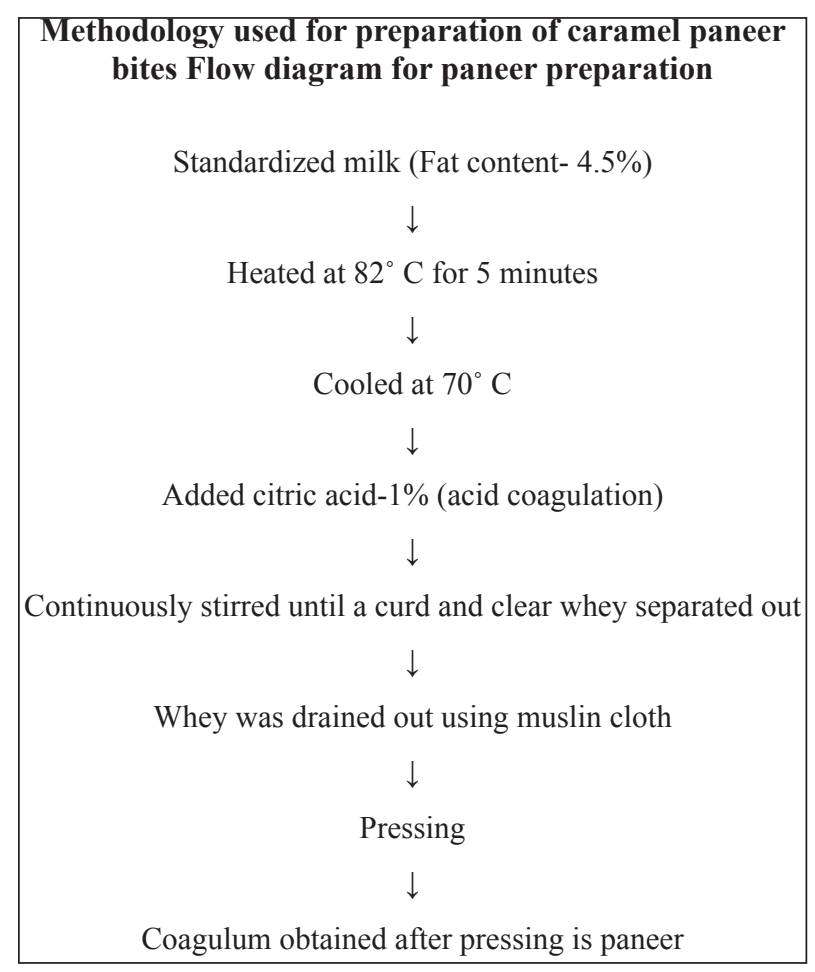

\section{Formulation of paneer bites}

All the four formulations were standardized on the basis of preliminary trials. The standardized formulations (table 1) were manually worked for 5-10 minutes to get smooth dough like texture and moulded into small balls of approximately $12 \mathrm{~g}$ weight by revolving between palms.

Table 1: Standardized formulation of cranberry infused caramel paneer bites

\begin{tabular}{|c|c|c|c|c|}
\hline SI. No. & Control & T1 & $\mathbf{T} 2$ & T3 \\
\hline Paneer (mashed) & $95 \mathrm{~g}$ & $92 \mathrm{~g}$ & $92 \mathrm{~g}$ & $92 \mathrm{~g}$ \\
\hline Milk powder & $5 g$ & $5 g$ & $5 \mathrm{~g}$ & $5 g$ \\
\hline Fruit Powder & - & 4g(MP) & 4g(GP) & $4 \mathrm{~g}(\mathrm{PP})$ \\
\hline Cranberry extract & & $\begin{array}{l}1 \% \text { in } \\
\text { caramel } \\
\text { coating }\end{array}$ & $\begin{array}{l}1 \% \text { in } \\
\text { caramel } \\
\text { coating }\end{array}$ & $\begin{array}{l}1 \% \text { in } \\
\text { caramel } \\
\text { coating }\end{array}$ \\
\hline
\end{tabular}

MP- mango powder, GP- grape powder, PP- pineapple powder. 


\section{Cooking at $50^{\circ} \mathrm{Bx}$ sugar syrup concentrations}

On the basis of preliminary trials, sugar solution of $50^{\circ} \mathrm{Bx}$ strength and cooking time of 10 minutes were preferred for the cooking of paneer bites. Sugar syrup was brought to boil and all the four formulations were cooked turn by turn at simmering temperature to avoid scorching of product. After cooking, paneer bites were left to cool aside followed by coating with cranberry infused caramel coating using silicon moulds.

\section{Preparation of cranberry infused caramel coating}

Ingredients for caramel preparation were standardized in the laboratory of LPT, SKUAST-Jammu by using fresh cream, brown sugar, milk powder, honey and vanilla essence. Fresh cream having 20-25\% fat was heated in a heavy bottom pan at low flame followed by addition of brown sugar, whole milk powder and honey in the sequence listed above. With the help of candy thermometer, temperature was continuously measured and caramel was constantly stirred to avoid scorching of the ingredients. Heavy bottom pan was off-flamed at $120^{\circ} \mathrm{C}$ followed by addition of cranberry extract. Using silicon moulds, paneer bites were coated immediately with caramel to avoid solidification in pan itself.

Table 2: List of ingredients added in caramel formulation

\begin{tabular}{ll}
\hline Ingredients for caramel preparation & $\begin{array}{l}\text { Quantity } \\
\mathbf{( 5 0 0 ~ g )}\end{array}$ \\
\hline Fresh Cream $(20-25 \%$ fat) & $200 \mathrm{~g}$ \\
Brown Sugar & $200 \mathrm{~g}$ \\
Whole milk powder (26\% fat) & $30 \mathrm{~g}$ \\
Honey & $70 \mathrm{~g}$ \\
Cranberry extract & $5 \mathrm{ml}$ \\
\hline
\end{tabular}

\section{Storage and analysis}

Cranberry infused caramel paneer bites were wrapped in butter paper and kept in LDPE pouches at refrigeration temperature of $\left(4 \pm 1^{\circ} \mathrm{C}\right)$ for shelf life studies up to spoilage.

\section{Analytical procedures}

$\mathrm{pH}$ of the samples was estimated with digital $\mathrm{pH}$ meter, Water activity (aw) was measured in the Department of
Food Science and Technology, SKUAST-Jammu using water activity meter Aqua Lab (Model Series 3 TE, Decagon Devices, USA). Total phenolic and flavonoid counts were estimated as per the spectrophotometric methods respectively (Singleton et al., 1999; Quettier et al., 2000). Thiobarbituric acid reacting substances (TBARS) value was determined following the method of Witte et al. (1970). Free fatty acid value was estimated as per the procedure of Koniecko (1979). Total plate count, coliform count and yeast mould count were determined as per the methods of APHA (1984). Sensory evaluation was performed for sensory attributes like colour and appearance, texture, aroma, flavour and overall acceptability using nine point hedonic scale following method of Pavon (2003), also, $\mathrm{P}$ and $\mathrm{K}$ 5-point hedonic testing on verbal liking scale was followed with slight modification by selecting 100 children randomly from Jammu city (Popper and Kroll, 2005) and Statistical analysis was done by using the software of statistical package for social sciences (SPSS 16.0) as per Snedecor and Cochran (1994).

\section{$P$ and $K$ hedonic testing}

All the four formulation were sensory evaluated with slight modification by using $\mathrm{P}$ and $\mathrm{K}$ 5-point hedonic testing on verbal liking scale with 100 children (6-15 yrs) selected randomly from Jammu city. Results were calculated as per the following formula:

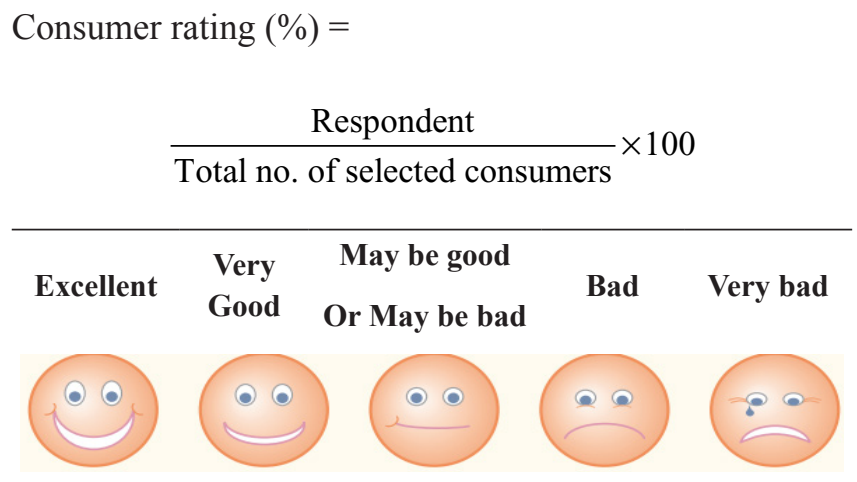

\section{RESULT AND DISCUSSION}

\section{$P$ and $K$ hedonic rating of the cranberry infused caramel paneer bites}

In accordance with the results obtained in table 3 , about $70 \%, 65 \%, 43 \%$ and $60 \%$, respondents scored the control, 
T1, T2 and T3 paneer bites as excellent confections whereas $29 \%, 29 \%, 54 \%$ and $38 \%$ respondents rated control, T1, T2 and T3 confections as very good. Among all the respondents, not a single consumer rated paneer bites in bad or worst category, although $1 \%, 6 \%, 3 \%$ and $2 \%$ respondents were not sure about the overall acceptability of the confections.

Table 3: $\mathrm{P}$ and $\mathrm{K}$ hedonic rating of the cranberry infused caramel paneer bites

\begin{tabular}{llllll}
\hline Treatments & Excellent & $\begin{array}{l}\text { Very } \\
\text { Good }\end{array}$ & $\begin{array}{l}\text { May be good } \\
\text { or bad }\end{array}$ & Bad & Worst \\
\hline Control & $70 \%$ & $29 \%$ & $1 \%$ & - & - \\
T1 & $65 \%$ & $29 \%$ & $6 \%$ & - & - \\
T2 & $43 \%$ & $54 \%$ & $3 \%$ & - & - \\
T3 & $60 \%$ & $38 \%$ & $2 \%$ & - & - \\
\hline
\end{tabular}

Control (mashed paneer + whole milk powder), T1 (mashed paneer + whole milk powder + mango powder + cranberry extract), $\mathrm{T} 2$ (mashed paneer + whole milk powder + grape powder + cranberry extract), T3 (mashed paneer + whole milk powder + pineapple powder + cranberry extract).

\section{Physico-chemical changes}

\section{pH and titratable acidity}

In accordance with the results displayed in table 4, significant $(\mathrm{P}<0.05)$ decrease was observed in the $\mathrm{pH}$ values of control samples throughout the storage period, however, in case of all the three treatments, significant $(\mathrm{P}<0.05)$ changes were observed from day 30 onwards. Decrease in $\mathrm{pH}$ values during storage of paneer bites, might be due to progressive escalation in microbial counts responsible for glycolytic changes. Similar variations have also been observed by Ashok and Dinesh (2018) and Neha et al. (2018) in gluten free gulab-jamun and Ashwagandha root extract added shrikhand samples during refrigeration storage. Results were also in accordance with the study of Rajender et al. (2019) on aerobically packed paneer nuggets stored at refrigeration storage. Nigam (2015) also noticed substantial decrease in average $\mathrm{pH}$ value of chhana based kulfi samples stored at $-18 \pm 2^{\circ} \mathrm{C}$ during 60 days of storage. The average $\mathrm{pH}$ values of all the cranberry infused caramel paneer bites were significantly $(\mathrm{P}<0.05)$ lower at almost all the days of storage relative to control samples due to addition of cranberry extract having key characteristic of acidic $\mathrm{pH}$ value.

Titratable acidity of the control and $\mathrm{T} 1$ paneer bites increased significantly $(\mathrm{P}<0.05)$ from day 30 onwards whereas in case of $\mathrm{T} 2$ and $\mathrm{T} 3$ paneer bites, increasing trend was observed ahead of day 45 and 60 of storage. However, the mean titratable acidity of all the treatments were significantly $(\mathrm{P}<0.05)$ higher on day 0 and 15 of refrigeration storage relative to the control paneer bites. The substantial increase in titratable acidity of the paneer bites might be due to proliferation of microorganisms which brought changes therein. Hossen et al. (2009) also reported significant $(\mathrm{P}<0.05)$ increase in acidity of guava confections due to fermentation and sugar hydrolysis during storage studies. Similar trends have also been reported by Bukhari et al. (2012) and Ahmad et al. (2014) in paneer and kaladi samples stored at refrigeration temperature. The increase in titratable acidity of paneer samples during storage was also supported by other scientific investigations (Rai et al., 2008; Ahuja and Goyal, 2013; Anju et al., 2017).

\section{Water activity}

Water activity of control samples increased significantly $(\mathrm{P}<0.05)$ ahead of day 30 , whereas for $\mathrm{T} 1$ and $\mathrm{T} 3$ similar changes were witnessed on day 60 and in case of T2, on day 45 and 60 of storage as displayed in table 4 . Accordingly, other scientists also reviewed a significant $(\mathrm{P}<0.05)$ increase in water activity during storage of sweet biscuits elaborated with recovered potato starch from fries industry effluents (Mariana et al. 2018). As per the scientific reports, increase in water activity is basically due to uptake of moisture, during storage of the processed foods (Sloan et al., 2016). Caramel confections with low moisture content contain sugars in the amorphous or glassy state which are highly hygroscopic and readily absorb moisture from the air, causing significant $(\mathrm{P}<0.05)$ changes that terminate the shelf life of the caramel based confections (Ergun et al., 2010).

\section{Free fatty acid (FFA)}

Mean FFA values of all the cranberry infused caramel paneer bites were significantly $(\mathrm{P}<0.05)$ lower at all the days of storage relative to control paneer bites. This 
might be due to anti-microbial action of cranberry extract preventing enzymatic fat hydrolysis. The FFA values of all the four formulations increased significantly $(\mathrm{P}<0.05)$ and this might be due to increase in the population of lipolytic bacteria during storage. In this context, Kaur et al. (2015) reported production of extracellular lipases by psychrotropic bacteria causing hydrolytic rancidity in milk and milk products. They further stated that increase in FFA content could also be due to fat degradation primarily by growth of yeast and mould. In the present investigation, yeast and mould count increased significantly $(\mathrm{P}<0.05)$ on storage which could be the reason for increased FFA content. As per the scientific reports of Vishal et al. (2015) increase in FFA content during storage might be due to degradation of fat content causing liberation of free fatty acids from the fat globules. Similar findings have also been reported in different milk products at refrigeration storage (Rai et al., 2007; Londhe et al., 2012; Ahuja and Goyal, 2013; Das et al., 2018).

\section{Thiobarbituric acid reactive substances (TBARS)}

So far as the TBARS value is concerned, there was a significant rise $(\mathrm{P}<0.05)$ in control samples from day 0 to 60 , whilst each treatment indicated significant $(\mathrm{P}<0.05)$ rise from day 15 to 60 . However, in case of all the treatments, significantly $(\mathrm{P}<0.05)$ lower TBARS values were analysed relative to control samples on all the days of storage. Perhaps, the phenolics in cranberry extract responded to free radical chain reactions by stabilizing and terminating them (Velasco and Williams, 2011). Biswas et al. (2012) reported $142.13 \pm 0.05 \mathrm{mg} / \mathrm{g}$ total phenolics in dry cranberries having positive effect on oxidative stress by diminishing secondary oxidative products generated during storage period. Das et al. (2018) also revealed substantial $(\mathrm{P}<0.05)$ hike in the values of TBARS performed on paneer samples infused with crude extract from dahi, nisin and lactic acid. Similarly, Meshref and Rowaily (2008) reported substantial hike in TBARS value, during heat processing of milk and milk products. Similar observations were reported by Ghayal et al. (2013) and Jha et al. (2013).

\section{Phenolic and flavonoid count}

A significant decrease $(p<0.05)$ was monitored in total phenolic count ahead of day 30 in $\mathrm{T} 1$ and $\mathrm{T} 2$ whereas in T3, similar trend was reported from day 15 onwards. For control paneer bites, phenolics were not detected throughout storage period, this might be due to absence of cranberry extract in control paneer bites. Decrease in total phenolic content has also been reported by Ana et al. (2020) during storage study of 4 months in white-tea based candies. Flavonoid count was detected only on day 0 in case of cranberry infused caramel paneer bites. This might be due to destruction of flavonoids on heating of caramel at $118-120^{\circ} \mathrm{C}$ temperature. Yadav et al. (2017) reported significant decrease in antioxidant activity by cooking at high temperatures. Yang and Choi (2017) compared different kinds of berries and reported highest concentration of phenolics in bokbunja followed by blackberry, mulberry, cranberry, raspberry, wild raspberry and strawberry. Biswas et al. (2012) also reported highest total phenolic content in frozen cranberries (616.65 \pm 0.14 $\mathrm{mg} / \mathrm{g})$ followed by sauces $(360.80 \pm 0.09 \mathrm{mg} / \mathrm{g})$, juices $(237.84 \pm 0.03 \mathrm{mg} / \mathrm{ml})$ and dry cranberries $(142.13 \pm 0.05$ $\mathrm{mg} / \mathrm{g})$.

\section{Proximate parameters}

No significant $(\mathrm{P}>0.05)$ changes were observed in fat, protein and ash content of control and cranberry infused caramel paneer bites, throughout the storage period (table 5). However, moisture content of control samples was significantly $(\mathrm{P}<0.05)$ higher on day 45 and 60 of storage as compared to cranberry infused treatments. Increase in moisture content might be attributed to increase in water activity of control samples with advancement of storage period. The moisture content plays a significant role in determining the microbial quality of the product during storage as it directly influences the shelf life of the product to a greater extent. The increase in moisture content during storage might be due to sudden oozing out of moisture from the product making it wet and sticky with increase in storage period.

\section{Changes in the microbial quality}

Total plate count of control and treatment formulations displayed in table 6 , escalated substantially $(p<0.05)$ on day 30 of storage. The Total plate count for control samples increased from $2.41 \log \mathrm{cfu} / \mathrm{g}$ (day 0) to $6.55 \mathrm{cfu} / \mathrm{g}$ (day 60), whereas for treatment formulations the upsurge was significantly lower on day 30, 45 and 60 compared 
Table 4: Physico-chemical changes in caramel paneer bites at refrigeration temperature $\left(4 \pm 1^{\circ} \mathrm{C}\right)$

\begin{tabular}{|c|c|c|c|c|c|}
\hline \multicolumn{6}{|c|}{ Storage Period (Days) } \\
\hline \multicolumn{6}{|c|}{$\mathrm{pH}$} \\
\hline Treatments & $\mathbf{0}$ & 15 & 30 & 45 & 60 \\
\hline Control & $6.88 \pm 0.077^{\mathrm{aA}}$ & $6.61 \pm 0.052^{\mathrm{aB}}$ & $6.45 \pm 0.086^{\mathrm{aBC}}$ & $6.23 \pm 0.063^{\mathrm{aCD}}$ & $6.08 \pm 0.102^{\mathrm{aD}}$ \\
\hline $\mathrm{T} 1$ & $6.17 \pm 0.044^{\mathrm{bA}}$ & $6.08 \pm 0.098^{\mathrm{bAB}}$ & $5.90 \pm 0.110^{\mathrm{bBC}}$ & $5.82 \pm 0.054^{\mathrm{bC}}$ & $5.73 \pm 0.053 \mathrm{bC}$ \\
\hline $\mathrm{T} 2$ & $6.13 \pm 0.041^{\mathrm{bA}}$ & $6.03 \pm 0.061 \mathrm{bAB}$ & $5.94 \pm 0.091^{\mathrm{Bbc}}$ & $5.83 \pm 0.062 \mathrm{bC}$ & $5.78 \pm 0.042^{\mathrm{bC}}$ \\
\hline $\mathrm{T} 3$ & $6.20 \pm 0.052^{\mathrm{bA}}$ & $6.10 \pm 0.044^{\mathrm{bAB}}$ & $5.98 \pm 0.074 \mathrm{bBC}$ & $5.86 \pm 0.081^{\mathrm{bCD}}$ & $5.70 \pm 0.070^{\mathrm{bD}}$ \\
\hline \multicolumn{6}{|c|}{ Titratable acidity (\% Lactic Acid) } \\
\hline Treatments & $\mathbf{0}$ & 15 & 30 & 45 & 60 \\
\hline Control & $0.265 \pm 0.0031^{\mathrm{bD}}$ & $0.273 \pm 0.0045^{\mathrm{bD}}$ & $0.293 \pm 0.0036^{\mathrm{C}}$ & $0.307 \pm 0.0063^{\mathrm{B}}$ & $0.327 \pm 0.0070^{\mathrm{A}}$ \\
\hline $\mathrm{T} 1$ & $0.291 \pm 0.0031^{\mathrm{aD}}$ & $0.299 \pm 0.0050^{\mathrm{aCD}}$ & $0.318 \pm 0.0041^{\mathrm{C}}$ & $0.322 \pm 0.0040^{\mathrm{B}}$ & $0.346 \pm 0.0044^{\mathrm{A}}$ \\
\hline $\mathrm{T} 2$ & $0.297 \pm 0.0053^{\mathrm{aC}}$ & $0.307 \pm 0.0087^{\mathrm{aC}}$ & $0.315 \pm 0.0053^{\mathrm{C}}$ & $0.321 \pm 0.0060^{\mathrm{B}}$ & $0.343 \pm 0.0088^{\mathrm{A}}$ \\
\hline $\mathrm{T} 3$ & $0.289 \pm 0.0043 \mathrm{aC}$ & $0.298 \pm 0.0075 \mathrm{aBC}$ & $0.320 \pm 0.0104^{\mathrm{BC}}$ & $0.319 \pm 0.0039^{\mathrm{AB}}$ & $0.348 \pm 0.0107^{\mathrm{A}}$ \\
\hline \multicolumn{6}{|c|}{ Water activity } \\
\hline Treatments & $\mathbf{0}$ & 15 & 30 & 45 & 60 \\
\hline Control & $0.852 \pm 0.0032^{\mathrm{D}}$ & $0.859 \pm 0.0053^{\mathrm{D}}$ & $0.873 \pm 0.0058^{\mathrm{C}}$ & $0.887 \pm 0.0037^{\mathrm{B}}$ & $0.910 \pm 0.0042^{\mathrm{A}}$ \\
\hline $\mathrm{T} 1$ & $0.860 \pm 0.0077^{\mathrm{B}}$ & $0.865 \pm 0.0092^{\mathrm{B}}$ & $0.872 \pm 0.0035 \mathrm{AB}$ & $0.878 \pm 0.0044 \mathrm{AB}$ & $0.885 \pm 0.0055^{\mathrm{A}}$ \\
\hline $\mathrm{T} 2$ & $0.862 \pm 0.0054^{\mathrm{B}}$ & $0.867 \pm 0.0035 \mathrm{AB}$ & $0.877 \pm 0.0073 \mathrm{AB}$ & $0.883 \pm 0.0048^{\mathrm{A}}$ & $0.886 \pm 0.0080^{\mathrm{A}}$ \\
\hline $\mathrm{T} 3$ & $0.863 \pm 0.0043^{\mathrm{B}}$ & $0.869 \pm 0.0046^{\mathrm{B}}$ & $0.874 \pm 0.0050^{\mathrm{AB}}$ & $0.880 \pm 0.0058^{\mathrm{AB}}$ & $0.888 \pm 0.0074^{\mathrm{A}}$ \\
\hline \multicolumn{6}{|c|}{ Free fatty acid (\% oleic acid) } \\
\hline Treatments & $\mathbf{0}$ & 15 & 30 & 45 & 60 \\
\hline Control & $0.200 \pm 0.0035 \mathrm{aE}$ & $0.273 \pm 0.0010^{\mathrm{aD}}$ & $0.354 \pm 0.0070^{\mathrm{aC}}$ & $0.497 \pm 0.0071^{\mathrm{aB}}$ & $0.634 \pm 0.0014^{\mathrm{aA}}$ \\
\hline $\mathrm{T} 1$ & $0.194 \pm 0.0012^{\mathrm{bE}}$ & $0.223 \pm 0.0012^{\mathrm{bD}}$ & $0.288 \pm 0.0026^{\mathrm{bC}}$ & $0.339 \pm 0.0052^{\mathrm{bB}}$ & $0.582 \pm 0.0009^{\mathrm{bA}}$ \\
\hline $\mathrm{T} 2$ & $0.191 \pm 0.0027^{\mathrm{bE}}$ & $0.220 \pm 0.0024 \mathrm{bD}$ & $0.280 \pm 0.0042 \mathrm{bC}$ & $0.334 \pm 0.0057^{\mathrm{bB}}$ & $0.575 \pm 0.0008^{\mathrm{cA}}$ \\
\hline $\mathrm{T} 3$ & $0.196 \pm 0.0011^{\mathrm{bE}}$ & $0.214 \pm 0.0034^{\mathrm{cD}}$ & $0.277 \pm 0.0082 \mathrm{bC}$ & $0.343 \pm 0.0010^{\mathrm{bB}}$ & $0.574 \pm 0.0009^{\mathrm{cA}}$ \\
\hline \multicolumn{6}{|c|}{ TBA (mg mal. / kg) } \\
\hline Treatments & $\mathbf{0}$ & 15 & 30 & 45 & 60 \\
\hline Control & $0.580 \pm 0.0161^{\mathrm{E}}$ & $0.695 \pm 0.0077 \mathrm{aD}$ & $0.887 \pm 0.0031^{\mathrm{aC}}$ & $1.22 \pm 0.0312^{\mathrm{aB}}$ & $1.71 \pm 0.0069^{\mathrm{aA}}$ \\
\hline $\mathrm{T} 1$ & $0.553 \pm 0.0089^{\mathrm{D}}$ & $0.572 \pm 0.0079^{\mathrm{bD}}$ & $0.766 \pm 0.0044 \mathrm{bC}$ & $0.834 \pm 0.010^{\mathrm{bB}}$ & $1.32 \pm 0.0084^{\mathrm{cA}}$ \\
\hline $\mathrm{T} 2$ & $0.547 \pm 0.0100^{\mathrm{D}}$ & $0.568 \pm 0.0083 \mathrm{bD}$ & $0.776 \pm 0.0040 \mathrm{bC}$ & $0.837 \pm 0.0109^{\mathrm{bB}}$ & $1.29 \pm 0.0121 \mathrm{cA}$ \\
\hline $\mathrm{T} 3$ & $0.560 \pm 0.0014^{\mathrm{D}}$ & $0.575 \pm 0.0065^{\mathrm{bD}}$ & $0.771 \pm 0.0037^{\mathrm{bC}}$ & $0.844 \pm 0.0078^{\mathrm{bB}}$ & $1.41 \pm 0.0041^{\mathrm{bA}}$ \\
\hline \multicolumn{6}{|c|}{ Total Phenolic count (mg GAE/100 g) } \\
\hline Treatments & $\mathbf{0}$ & 15 & 30 & 45 & 60 \\
\hline $\mathrm{T} 1$ & $46.4 \pm 0.033^{\mathrm{A}}$ & $36.6 \pm 0.037^{\mathrm{A}}$ & $18.0 \pm 0.051^{\mathrm{B}}$ & $7.1 \pm 0.010^{\mathrm{B}}$ & ND \\
\hline $\mathrm{T} 2$ & $47.1 \pm 0.035^{\mathrm{A}}$ & $36.4 \pm 0.038^{\mathrm{A}}$ & $18.6 \pm 0.046^{\mathrm{B}}$ & $6.5 \pm 0.007^{\mathrm{C}}$ & ND \\
\hline $\mathrm{T} 3$ & $46.7 \pm 0.029^{\mathrm{A}}$ & $36.0 \pm 0.025^{\mathrm{B}}$ & $17.1 \pm 0.033^{\mathrm{C}}$ & $7.1 \pm 0.021^{\mathrm{D}}$ & ND \\
\hline \multicolumn{6}{|c|}{$\begin{array}{c}\text { Total flavonoid count (mg QE/100 g) } \\
\end{array}$} \\
\hline Treatments & $\mathbf{0}$ & 15 & 30 & 45 & \\
\hline T1 & $1.20 \pm 0.037$ & ND & ND & ND & ND \\
\hline $\mathrm{T} 2$ & $1.48 \pm 0.009$ & ND & ND & ND & ND \\
\hline $\mathrm{T} 3$ & $1.13 \pm 0.074$ & ND & ND & ND & ND \\
\hline
\end{tabular}

* Mean \pm SE with different superscripts in a row wise (upper case alphabet) and column wise (lower case alphabet) differ significantly $(\mathrm{p}<0.05) . \mathrm{n}_{1}=6$ for each treatment, ND- Not Detected, Control (mashed paneer + whole milk powder), T1 (mashed paneer + whole milk powder + mango powder + cranberry extract), $\mathrm{T} 2$ (mashed paneer + whole milk powder + grape powder + canberry extract), T3 (mashed paneer + whole milk powder + pineapple powder + cranberry extract). 
Table 5: Proximate composition of caramel paneer bites at refrigeration temperature $\left(4 \pm 1^{\circ} \mathrm{C}\right)$

\begin{tabular}{|c|c|c|c|c|c|}
\hline \multicolumn{6}{|c|}{ Storage Period (Days) } \\
\hline \multicolumn{6}{|c|}{ Moisture (\%) } \\
\hline Treatments & $\mathbf{0}$ & 15 & 30 & 45 & 60 \\
\hline Control & $19.67 \pm 0.36^{\mathrm{D}}$ & $20.80 \pm 0.41^{\mathrm{C}}$ & $21.97 \pm 0.44^{\mathrm{B}}$ & $23.22 \pm 0.18^{\mathrm{aA}}$ & $23.83 \pm 0.23^{\mathrm{aA}}$ \\
\hline $\mathrm{T} 1$ & $20.80 \pm 0.86$ & $20.92 \pm 0.52$ & $21.06 \pm 0.43$ & $21.29 \pm 0.80^{b}$ & $21.68 \pm 0.64^{b}$ \\
\hline $\mathrm{T} 2$ & $20.74 \pm 0.34$ & $20.86 \pm 0.58$ & $21.04 \pm 0.61$ & $21.20 \pm 0.41^{\mathrm{b}}$ & $21.59 \pm 0.71^{b}$ \\
\hline $\mathrm{T} 3$ & $20.89 \pm 0.48$ & $20.96 \pm 0.66$ & $21.10 \pm 0.62$ & $21.30 \pm 0.36^{\mathrm{b}}$ & $21.63 \pm 0.70^{\mathrm{b}}$ \\
\hline \multicolumn{6}{|c|}{ Fat (\%) } \\
\hline Treatments & $\mathbf{0}$ & 15 & 30 & 45 & 60 \\
\hline Control & $16.12 \pm 0.15$ & $15.97 \pm 0.29$ & $15.83 \pm 0.26$ & $15.64 \pm 0.22$ & $15.48 \pm 0.27$ \\
\hline $\mathrm{T} 1$ & $15.90 \pm 0.30$ & $15.83 \pm 0.23$ & $15.65 \pm 0.34$ & $15.39 \pm 0.17$ & $15.29 \pm 0.25$ \\
\hline $\mathrm{T} 2$ & $15.88 \pm 0.39$ & $15.73 \pm 0.21$ & $15.70 \pm 0.27$ & $15.54 \pm 0.18$ & $15.34 \pm 0.27$ \\
\hline $\mathrm{T} 3$ & $15.94 \pm 0.21$ & $15.70 \pm 0.18$ & $15.61 \pm 0.32$ & $15.47 \pm 0.15$ & $15.39 \pm 0.26$ \\
\hline \multicolumn{6}{|c|}{ Protein $(\%)$} \\
\hline Treatments & $\mathbf{0}$ & 15 & 30 & 45 & 60 \\
\hline Control & $12.90 \pm 0.31$ & $12.84 \pm 0.22$ & $12.71 \pm 0.19$ & $12.48 \pm 0.21$ & $12.26 \pm 0.53$ \\
\hline $\mathrm{T} 1$ & $12.70 \pm 0.38$ & $12.62 \pm 0.34$ & $12.58 \pm 0.41$ & $12.33 \pm 0.17$ & $12.06 \pm 0.46$ \\
\hline $\mathrm{T} 2$ & $12.65 \pm 0.41$ & $12.58 \pm 0.34$ & $12.54 \pm 0.44$ & $12.26 \pm 0.26$ & $12.02 \pm 0.44$ \\
\hline $\mathrm{T} 3$ & $12.79 \pm 0.61$ & $12.68 \pm 0.39$ & $12.63 \pm 0.28$ & $12.29 \pm 0.46$ & $12.11 \pm 0.65$ \\
\hline \multicolumn{6}{|c|}{ Ash (\%) } \\
\hline Treatments & $\mathbf{0}$ & 15 & 30 & 45 & 60 \\
\hline Control & $0.76 \pm 0.041$ & $0.82 \pm 0.051$ & $0.86 \pm 0.096$ & $0.93 \pm 0.089$ & $0.98 \pm 0.060$ \\
\hline $\mathrm{T} 1$ & $0.85 \pm 0.066$ & $0.88 \pm 0.073$ & $0.91 \pm 0.078$ & $0.98 \pm 0.069$ & $1.06 \pm 0.056$ \\
\hline $\mathrm{T} 2$ & $0.83 \pm 0.079$ & $0.91 \pm 0.051$ & $0.87 \pm 0.055$ & $0.96 \pm 0.072$ & $1.03 \pm 0.048$ \\
\hline $\mathrm{T} 3$ & $0.89 \pm 0.062$ & $0.90 \pm 0.045$ & $0.95 \pm 0.055$ & $0.99 \pm 0.064$ & $1.08 \pm 0.045$ \\
\hline
\end{tabular}

* Mean \pm SE with different superscripts in a row wise (upper case alphabet) and column wise (lower case alphabet) differ significantly $(p<0.05) . n_{1}=6$ for each treatment, Control (mashed paneer + whole milk powder), T1 (mashed paneer + whole milk powder + mango powder + cranberry extract), T2 (mashed paneer + whole milk powder + grape powder + cranberry extract), T3 (mashed paneer + whole milk powder + pineapple powder + cranberry extract).

to control samples. Yeast and mould (Y\&M) count was negligible to enumerate on day 0 and 15 of storage, however, on day 30, the counts were 2.62, 1.72, 1.69 and $1.63 \mathrm{log} \mathrm{cfu} / \mathrm{g}$ for control, T1, T2 and T3 respectively. On day 30,45 and $60 \mathrm{Y} \& \mathrm{M}$ count was significantly $(\mathrm{P}<0.05)$ lower in treatment formulations relative to control samples. On day 45, TPC and Y\&M counts were 5.58 and 2.62 $\log \mathrm{cfu} / \mathrm{g}$ in control paneer bites and according to Food safety and standard regulations (2011), the maximum threshold limit for TPC and Y\&M count in paneer is $5.54 \mathrm{log} \mathrm{cfu} / \mathrm{g}$ and $2.17 \mathrm{log} \mathrm{cfu} / \mathrm{g}$ respectively. However, in case of cranberry infused paneer bites, the TPC and Y\&M counts on day 45 were below the permissible limit. Coliform count was not detected in paneer bite samples throughout the storage studies suggesting good hygienic quality in processing. Similarly, Sengar (2013) reported no coliform count in cham cham samples at refrigeration storage. The unacceptability in the context of microbial quality had been declared on day 45 for control samples and on day 60 for cranberry infused caramel paneer bites. Other scientists also reported significant $(\mathrm{P}<0.05)$ increase in TPC and YMC in variety of milk products packed in diverse packages (Anju, 2017; Ashok and Dinesh, 2018; Das et al., 2018). For most of the indigenous dairy products Y\&M growth tends to be a major problem and often most important single factor, limiting their shelflife. Yeast and moulds are undesirable and their presence in sufficient numbers tends to reduce the keeping quality of dairy products. Hence, it is considered an important parameter of study. 
Table 6: Microbial characteristics of caramel paneer bites at refrigeration temperature $\left(4 \pm 1^{\circ} \mathrm{C}\right)$

\begin{tabular}{|c|c|c|c|c|c|}
\hline \multicolumn{6}{|c|}{ Storage Period (Days) } \\
\hline \multicolumn{6}{|c|}{ Total plate count (log cfu/g) } \\
\hline Treatments & $\mathbf{0}$ & 15 & 30 & 45 & 60 \\
\hline Control & $2.41 \pm 0.034^{\mathrm{D}}$ & $2.62 \pm 0.091^{\mathrm{D}}$ & $3.83 \pm 0.073^{\mathrm{aC}}$ & $5.58 \pm 0.130^{\mathrm{aB}}$ & $6.55 \pm 0 . .117^{\mathrm{aA}}$ \\
\hline $\mathrm{T} 1$ & $2.38 \pm 0.040^{\mathrm{D}}$ & $2.51 \pm 0.072^{\mathrm{D}}$ & $2.75 \pm 0.085^{\mathrm{bC}}$ & $4.19 \pm 0.096^{\mathrm{bB}}$ & $4.87 \pm 0.032 \mathrm{bA}$ \\
\hline $\mathrm{T} 2$ & $2.27 \pm 0.054^{\mathrm{D}}$ & $2.58 \pm 0.062^{\mathrm{C}}$ & $2.68 \pm 0.067 \mathrm{bC}$ & $4.23 \pm 0.084^{\mathrm{bB}}$ & $4.79 \pm 0.065^{\mathrm{bA}}$ \\
\hline $\mathrm{T} 3$ & $2.34 \pm 0.055^{\mathrm{D}}$ & $2.48 \pm 0.090 \mathrm{CD}$ & $2.59 \pm 0.048^{\mathrm{bC}}$ & $4.14 \pm 0.077^{\mathrm{bB}}$ & $4.83 \pm 0.033^{\mathrm{bA}}$ \\
\hline \multicolumn{6}{|c|}{ Coliform count $(\log$ cfu/g) } \\
\hline Treatments & $\mathbf{0}$ & 15 & 30 & 45 & 60 \\
\hline Control & ND & ND & ND & ND & ND \\
\hline $\mathrm{T} 1$ & ND & ND & ND & ND & ND \\
\hline $\mathrm{T} 2$ & ND & ND & ND & ND & ND \\
\hline $\mathrm{T} 3$ & ND & ND & ND & ND & ND \\
\hline \multicolumn{6}{|c|}{ Y\&M count $(\log$ cfu/g) } \\
\hline Treatments & $\mathbf{0}$ & 15 & 30 & 45 & 60 \\
\hline Control & ND & ND & $1.59 \pm 0.089^{\mathrm{aC}}$ & $2.62 \pm 0.081 \mathrm{aB}$ & $3.84 \pm 0.034^{\mathrm{Aa}}$ \\
\hline $\mathrm{T} 1$ & ND & ND & $1.28 \pm 0.034^{\mathrm{bB}}$ & $1.72 \pm 0.079^{\mathrm{bB}}$ & $2.49 \pm 0.099^{\mathrm{bA}}$ \\
\hline $\mathrm{T} 2$ & ND & ND & $1.20 \pm 0.031^{\mathrm{bB}}$ & $1.69 \pm 0.041^{\mathrm{bB}}$ & $2.53 \pm 0.041^{\mathrm{Ba}}$ \\
\hline $\mathrm{T} 3$ & ND & ND & $1.32 \pm 0.052^{\mathrm{bB}}$ & $1.63 \pm 0.045^{\mathrm{bAB}}$ & $2.43 \pm 0.093^{\mathrm{Ba}}$ \\
\hline
\end{tabular}

* Mean \pm SE with different superscripts in a row wise (upper case alphabet) and column wise (lower case alphabet) differ significantly $(\mathrm{p}<0.05) . \mathrm{n}_{1}=6$ for each treatment, ND- Not Detected, Control (mashed paneer + whole milk powder), T1 (mashed paneer + whole milk powder + mango powder + cranberry extract), T2 (mashed paneer + whole milk powder + grape powder + cranberry extract), T3 (mashed paneer + whole milk powder + pineapple powder + cranberry extract.

Table 7: Sensory characteristics of caramel paneer bites at refrigeration temperature $\left(4 \pm 1^{\circ} \mathrm{C}\right)$

\begin{tabular}{|c|c|c|c|c|c|}
\hline \multicolumn{6}{|c|}{ Storage Period (Days) } \\
\hline \multicolumn{6}{|c|}{ Colour and appearance } \\
\hline Treatments & $\mathbf{0}$ & 15 & 30 & 45 & 60 \\
\hline Control & $8.18 \pm 0.15^{\mathrm{A}}$ & $7.70 \pm 0.12^{\mathrm{AB}}$ & $7.21 \pm 0.19^{\mathrm{B}}$ & $6.16 \pm 0.18^{\mathrm{bC}}$ & $5.34 \pm 0.21^{\mathrm{D}}$ \\
\hline $\mathrm{T} 1$ & $8.22 \pm 0.15^{\mathrm{A}}$ & $7.75 \pm 0.15^{\text {B }}$ & $7.69 \pm 0.20^{\mathrm{B}}$ & $6.84 \pm 0.18^{\mathrm{aC}}$ & $5.42 \pm 0.13^{\mathrm{D}}$ \\
\hline $\mathrm{T} 2$ & $8.29 \pm 0.17^{\mathrm{A}}$ & $7.79 \pm 0.13^{\mathrm{B}}$ & $7.64 \pm 0.13^{\text {B }}$ & $6.83 \pm 0.15 \mathrm{aC}$ & $5.40 \pm 0.21^{\mathrm{D}}$ \\
\hline $\mathrm{T} 3$ & $8.27 \pm 0.09^{\mathrm{A}}$ & $7.73 \pm 0.13^{\mathrm{B}}$ & $7.66 \pm 0.14^{\mathrm{B}}$ & $6.87 \pm 0.16^{\mathrm{aC}}$ & $5.43 \pm 0.16^{\mathrm{D}}$ \\
\hline \multicolumn{6}{|c|}{ Texture } \\
\hline Treatments & $\mathbf{0}$ & 15 & 30 & 45 & 60 \\
\hline Control & $8.27 \pm 0.13^{\mathrm{A}}$ & $8.20 \pm 0.18^{\mathrm{A}}$ & $7.86 \pm 0.15^{\mathrm{AB}}$ & $6.72 \pm 0.15^{\mathrm{B}}$ & $6.10 \pm 0.20^{\mathrm{C}}$ \\
\hline $\mathrm{T} 1$ & $8.11 \pm 0.16^{\mathrm{A}}$ & $7.93 \pm 0.17^{\mathrm{A}}$ & $7.74 \pm 0.18^{\mathrm{A}}$ & $6.61 \pm 0.15^{\text {B }}$ & $5.91 \pm 0.22^{\mathrm{B}}$ \\
\hline $\mathrm{T} 2$ & $8.13 \pm 0.18^{\mathrm{A}}$ & $8.01 \pm 0.20^{\mathrm{A}}$ & $7.72 \pm 0.21^{\mathrm{A}}$ & $6.60 \pm 0.20^{\text {B }}$ & $5.95 \pm 0.24^{\mathrm{C}}$ \\
\hline $\mathrm{T} 3$ & $8.14 \pm 0.16^{\mathrm{A}}$ & $7.96 \pm 0.17^{\mathrm{A}}$ & $7.77 \pm 0.20^{\mathrm{A}}$ & $6.59 \pm 0.16^{\mathrm{B}}$ & $5.88 \pm 0.21^{\mathrm{C}}$ \\
\hline \multicolumn{6}{|c|}{ Aroma } \\
\hline Treatments & $\mathbf{0}$ & 15 & 30 & 45 & 60 \\
\hline Control & $8.31 \pm 0.14^{\mathrm{A}}$ & $7.65 \pm 0.14^{\mathrm{bA}}$ & $7.13 \pm 0.21^{\mathrm{B}}$ & $6.25 \pm 0.14^{\mathrm{C}}$ & $5.95 \pm 0.16^{\mathrm{C}}$ \\
\hline $\mathrm{T} 1$ & $8.56 \pm 0.09^{A}$ & $8.20 \pm 0.16^{\mathrm{aA}}$ & $7.41 \pm 0.17^{\text {B }}$ & $6.39 \pm 0.13^{\mathrm{C}}$ & $6.12 \pm 0.13^{\mathrm{C}}$ \\
\hline $\mathrm{T} 2$ & $8.50 \pm 0.10^{\mathrm{A}}$ & $8.10 \pm 0.18^{\mathrm{abA}}$ & $7.40 \pm 0.16^{\mathrm{B}}$ & $6.33 \pm 0.15^{\mathrm{C}}$ & $6.07 \pm 0.15^{\mathrm{C}}$ \\
\hline $\mathrm{T} 3$ & $8.53 \pm 0.13^{\mathrm{A}}$ & $8.18 \pm 0.16^{\mathrm{aA}}$ & $7.38 \pm 0.19^{\mathrm{B}}$ & $6.37 \pm 0.17^{\mathrm{C}}$ & $6.09 \pm 0.12^{\mathrm{C}}$ \\
\hline
\end{tabular}




\begin{tabular}{llllll}
\hline \multicolumn{7}{c}{ Flavour } \\
\hline Treatments & $\mathbf{0}$ & $\mathbf{1 5}$ & $\mathbf{3 0}$ & $\mathbf{4 5}$ & $\mathbf{6 0}$ \\
\hline Control & $8.20 \pm 0.13^{\mathrm{A}}$ & $7.83 \pm 0.16^{\mathrm{A}}$ & $7.13 \pm 0.13^{\mathrm{bB}}$ & $\mathrm{NP}$ & $\mathrm{NP}$ \\
$\mathrm{T} 1$ & $8.28 \pm 0.11^{\mathrm{A}}$ & $7.95 \pm 0.14^{\mathrm{AB}}$ & $7.78 \pm 0.11^{\mathrm{aB}}$ & $6.52 \pm 0.21^{\mathrm{C}}$ & $\mathrm{NP}$ \\
$\mathrm{T} 2$ & $8.27 \pm 0.17^{\mathrm{A}}$ & $7.93 \pm 0.14^{\mathrm{AB}}$ & $7.73 \pm 0.11^{\mathrm{aB}}$ & $6.56 \pm 0.19^{\mathrm{C}}$ & $\mathrm{NP}$ \\
T3 & $8.25 \pm 0.19^{\mathrm{A}}$ & $7.92 \pm 0.15^{\mathrm{A}}$ & $7.76 \pm 0.12^{\mathrm{aA}}$ & $6.53 \pm 0.18^{\mathrm{B}}$ & $\mathrm{NP}$ \\
\hline \multicolumn{7}{c}{ Overall acceptability } \\
\hline Treatments & $\mathbf{0}$ & $\mathbf{1 5}$ & $\mathbf{3 0}$ & $\mathbf{4 5}$ & $\mathbf{6 0}$ \\
\hline Control & $8.22 \pm 0.16^{\mathrm{A}}$ & $7.76 \pm 0.14^{\mathrm{B}}$ & $7.24 \pm 0.17^{\mathrm{C}}$ & $5.83 \pm 0.12^{\mathrm{bD}}$ & $5.26 \pm 0.17^{\mathrm{E}}$ \\
T1 & $8.28 \pm 0.15^{\mathrm{A}}$ & $7.83 \pm 0.18^{\mathrm{AB}}$ & $7.69 \pm 023^{\mathrm{B}}$ & $6.28 \pm 0.13^{\mathrm{aC}}$ & $5.73 \pm 0.20^{\mathrm{D}}$ \\
T2 & $8.23 \pm 0.16^{\mathrm{A}}$ & $7.84 \pm 0.17^{\mathrm{AB}}$ & $7.65 \pm 0.19^{\mathrm{B}}$ & $6.26 \pm 0.13^{\mathrm{aC}}$ & $5.72 \pm 0.18^{\mathrm{D}}$ \\
T3 & $8.25 \pm 0.22^{\mathrm{A}}$ & $7.80 \pm 0.21^{\mathrm{A}}$ & $7.68 \pm 0.24^{\mathrm{A}}$ & $6.24 \pm 0.12^{\mathrm{aB}}$ & $5.70 \pm 0.21^{\mathrm{B}}$ \\
\hline
\end{tabular}

* Mean \pm SE with different superscripts in a row wise (upper case alphabet) and column wise (lower case alphabet) differ significantly (p $<0.05$ ). $\mathrm{n}_{1}=21$ for each treatment, NP- Not Performed, Control (mashed paneer + whole milk powder), T1 (mashed paneer + whole milk powder + mango powder + cranberry extract), $\mathrm{T} 2$ (mashed paneer + whole milk powder + grape powder + cranberry extract). T3 (mashed paneer + whole milk powder + pineapple powder + cranberry extract).

\section{Organoleptic changes}

Variations in the score card proforma of organoleptic attributes of control and treatment formulations are displayed in table 7. Significant $(\mathrm{P}<0.05)$ decrease in colour and appearance scores of control samples were witnessed on day 45 of storage, relative to treatment formulations. Perhaps, it could be attributed to spoilage of control paneer bites on day 45, whereas, anti-oxidant property of cranberry extract protected the treatment formulations against microbial spoilage. Decrease in organoleptic attributes with progress in storage period, primarily a consequence of maillard reactions, oxidative discolouration and moisture vaporization etc (Thivani et al., 2016). Results were in consonance with the trials of Sengar (2013) and Tiwari (2013) on cham-cham and burfi refrigerated at $7 \pm 2{ }^{\circ} \mathrm{C}$ respectively. Neha et al. (2018) also revealed significant $(\mathrm{P}<0.05)$ fall in colour and appearance scores of gluten free gulab-jamun during entire duration of storage. Texture scores also declined $(\mathrm{P}<0.05)$ significantly on account of increase in products' stickiness. Flavour scores were significantly $(\mathrm{P}<0.05)$ higher for all the treatments on day 30 as compared to control formulations.

However, aroma scores for all the treatment formulations were substantially $(\mathrm{P}<0.05)$ superior relative to control samples on day 15 of storage. Probably, it is due to the presence of aroma precursors in fruit powders. A significant $(\mathrm{P}<0.05)$ decline was also witnessed in the overall acceptability scores of all the formulation during entire storage as a consequence of decline in other organoleptic attributes. The findings were in resemblance with the published research data of other scientists during storage of variety of milk products at different temperatures (Anju, 2017; Ashok and Dinesh, 2018; Yoo et al., 2019).

\section{CONCLUSION}

On the strength of results obtained, it is potentially concluded that ahead of day 30, microbial quality of control samples declined substantially, whereas treatment samples were found to be acceptable up to day 45 of storage at temperature of $4 \pm 1^{\circ} \mathrm{C}$ in aerobic packaging. With the aid of all natural ingredients, new innovative strategy has been exploited to develop cranberry infused caramel paneer bites with shelf life of 45 days for school going children.

\section{ACKNOWLEDGEMENTS}

I extend sincere gratitude to my advisor 'Dr Sunil Kumar' Head of Department, LPT for designing this research work. I also extend my gratitude towards SKUAST-Jammu University for providing infrastructure for the smooth conduct of research. Also, credit for successful conduct of this research goes to non-teaching staff of Department of LPT, who provided equipments, chemicals and all the glassware as and when needed.

\section{REFERENCES}

Ahmad, S.R., Pathak, V., Bhat, Z. F. and Bukhari, S.A.A. 2014. Effect of sorbic acid on the storage quality of Kaladhi-an 
acid coagulated milk product. . J. Food Sci. Technol., 51(12): 4040-4046.

Ahuja, Kunal, K. and Goyal, G.K. 2013. Combined effect of vacuum packaging and refrigerated storage on the chemical quality of paneer tikka. J. Food Sci. Technol., 50(3): 620-623.

Ana, M., Danijela, S., Mario, S., Aleksandra, V. C., Ana, B. C. and Zenka, K. 2020. Physicochemical, bioactive and sensory assessment of white tea based candies during 4 months storage. J. Food Process. Preserv., 44(8): e14628.

Anju, B.K., Ray, A. and Kaur, A. 2017. Studies on shelf life extension of paneer with the addition of plant essential oil and different packaging materials. Int. J. Curr. Microbiol. App. Sci., 6(9): 376-389.

APHA. 1984. Compendium of methods for the microbiological examination of foods. $2^{\text {nd }}$ edition. American Public Health Association, Washington, DC.

Ashok, K. and Dinesh, C. R. 2018. Comparative study of the physico-chemical and functional properties of Ashwagandha root extract enriched shrikhand and control shrikhand during storage. J. Pharmacognosy Phytochem., 7: 1172-1179.

Biswas, N., Balac, P., Narlakanti, S.K., Haque, M.D.E. and Hassan, M.D.M. 2013. Identification of phenolic compounds in processed cranberries by HPLC method. J. Nutr. Food Sci., 3:1-5.

Blumberg, J.B., Camesano, T.A., Cassidy, A., Kris-Etherton, P. and Howell, A. 2013. Cranberries and their bioactive constituents in human health. Adv. Nutri., 4(6): 618-632.

Bukhari, S.A.A., Pathak, V., Bhat, Z.F. and Ahmed, S R. 2012. Effect of ambient storage on the quality characteristics of Kaladhi-an acid coagulated milk product. Am. J. Food Technol., 7(4): 192-203.

Das, A., Geeta, C., Ravi, K.A., Serlene, T. and Kaushik, S. 2018. Comparative study on evaluation of refrigerated $\left(4 \pm 1^{\circ} \mathrm{C}\right)$ storage stability of paneer incorporated with crude extract from indian curd, nisin and lactic Acid. It. J. Curr. Microbiol. App. Sci., 7(4): 167-180.

Ergun, R.R., Lietha and Hartel, R.W. 2010. Moisture and shelf life in sugar confections. Crit. Rev. Food Sci. Nutri., 50(2): 162-192.

Ghayal, G., Jha, A., Arvind, G.A.K. and Rasane, P. 2013. Effect of modified atmospheric packaging on physico-chemical and microbial changes in dietetic Rabri during storage. J. Food Sci. Technol., 52(3): 1825-1829.

Hossen, S., Kabir, M.S., Uddin, M.B., Rahman, A.K. and Mamun, M.R.A. 2009. Effect of different extractions of juice on quality and acceptability of guava jelly. J. Innov. Dev. Strat., 3: 27-35.

Jha, A., Arvind, Jain, P., Gautam, A.K. and Rasane, P. 2013. Effect of modified atmosphere packaging on the shelf life of Lalpeda. J. Food. Sci. Technol., 52(2):1068-1074.
Kaur, S., Kumar, S. and Kaur, R. 2018. Physicochemical and organoleptic properties of caramel coated chhana confection incorporated with mango and pineapple powder. Int. J. Curr. Microbiol. App. Sci., 7(8): 3110-3120.

Koniecko, E.S. 1979. Handbook for Meat Chemists. Avery Publishing Group, New York, U.S.A. pp 53-55.

Londhe, G., Pal, D. and Raju, P.N. 2012. Effect of packaging techniques on shelf life of brown peda, a milk-based confection. J. Food Sci. Technol., 47: 117-125.

Mariana, M.P.D., Caliari, M., Nabeshima, E.H. and Soares, J.M.S. 2018. Storage stability of sweet biscuit elaborated with recovered potato starch from effluent of fries industry. Food Sci. Technol., 38(2): 216-222.

Meshref, A. and Rowaily. 2008. Effect of heating treatments, processing methods and refrigerated storage of milk and some dairy products on lipids oxidation. Pakistan J. Nutr., 7: $118-125$.

Neha, V.M. and Paul, P. and Pinto, S. 2018. Effect of storage on physico-chemical, sensory and microbiological quality of gluten-free gulabjamun. Pharma Innov. J., 7(6): 612-619.

Nigam, R. 2015. Development of technology for Chhana based Kulfi. PG thesis, National Dairy Research Institute, Karnal, Haryana, India.

Paredes, L.O., Cervantes, M.L., Vigna, M. and Hernandez, T. 2010. Berries: improving human health and healthy aging, and promoting quality life-a review. Plant Foods Hum Nutr., 65: 299-308.

Pavon, N.R. 2003. Sensory characteristics of flavored milk candies. PG thesis, Louisiana State University, Louisian.

Popper, R. and Kroll, J.J. 2005. Conducting sensory research with children. J. Sens. Stud., 20(1): 75-87.

Quettier, D.C., Gressier, B. and Vasseur, J. 2000. Phenolic compounds and antioxidant activities of buckwheat hulls and flour. J. Ethnopharmacol., 72(1): 35-42.

Rai, S., Goyal, G.K. and Rai, G.K. 2008. Effect of modified atmosphere packaging (MAP) and storage on the chemical quality of paneer. J. Dairying, Foods Home Sci., 27(1): 3337.

Rajender, K., Sivakumar, S. and Rekha, C. 2019. Effect of storage conditions on physico-chemical parameters of aerobically packed paneer nuggets: A ready to eat snack food. Int. J. Chem. Stud., 7(3): 3889-3894.

Sengar, A. 2013. Process standardization for manufacture of cham-cham. PG thesis, Anand Agricultural University, Gujarat, India.

Shrivastava, S. and Goyal, G.K. 2007. Preparation of paneer: a review. Indian J. Dairy Sci., 60(6): 377-388. 
Singleton, V.L., Orthofer, R. and Lamuela, R.M. 1999. Analysis of total phenols and other oxidation substrates and antioxidants by means of folin-ciocalteu reagent. Methods Enzym., 299: 152-178.

Sloan, A.R., Dunn, M. and Steele, F.M. 2016. Effect of water activity and packaging material on the quality of dehydrated Taro (Colocasia esculenta (L.) Schott) slices during accelerated storage. Int. J. Food Sci., 11: 1-9.

Snedecor, G.W. and Cochran W.G. 1994. Statistical Methods $\left(6^{\text {th }}\right.$ edition). Oxford and IBH Publishing Co., New Delhi, India.

Thivani, M., Mahendren, T. and Kanimoly, M. 2016. Study on the physico-chemical properties, sensory attributes and shelf life of pineapple powder incorporated biscuits. Ruhuna $J$. Sci., 7: 32-42.

Tiwari, A. 2013. Assessing the suitability of sweet cream buttermilk in preparation of Burfi. PG thesis, Anand Agricultural University, Gujarat, India.

Velasco, V and Williams, P. 2011. Improving meat quality through natural antioxidants. Chilean J. Agri. Res., 71(2): 313-322.
Vishal, J., Rasane, P., Jha, A., Sharma, N. and Gautam, A. 2015. Effect of modified atmospheric packaging on the shelf life of kalakand and its influence on microbial, textural, sensory and physico-chemical properties. J. Food Sci. Technol., 52(7): 4090-4101.

Witte, V.C., Krause, G.F. and Bailey, M.E. 1970. A new extraction method for determining 2-thiobarbituric acid value of pork and beef during storage. J. Food Sci., 35: 582-585.

Yadav, R., Yadav, B.S. and Yadav, R.B. 2017. Effect of heat processing treatments and extraction solvents on the phenolic content and antioxidant activity of Momordica charantia fruit. J. Food Process. Preserv., 41(4): e13037.

Yang, J.W. and Choi, I.S. 2017. Comparison of the phenolic composition and antioxidant activity of Korean black raspberry, bokbunja with those of six other berries. CyTA-J. Food., 15(1): 110-117.

Yoo. J., Song, M., Park, W., Oh, S., Ham, J.S., Jeong, S.G. and Kim, Y. 2019. A comparison of quality characteristics in dairy products made from Jersey and Holstein milk. Food Sci. Anim. Res., 39(2): 255-265. 
